\title{
In Vitro Evaluation of the Odontogenic Potential of Mouse Undifferentiated Pulp Cells
}

\author{
Mayara Sgarbi SEMEGHINI ${ }^{1}$ \\ Roger Rodrigo FERNANDES ${ }^{1}$ \\ Daniela Thomazatti CHIMELLO ${ }^{1}$ \\ Fabíola Singaretti de OLIVEIRA ${ }^{2}$ \\ Karina Fittipaldi BOMBONATO-PRADO ${ }^{1}$

\begin{abstract}
${ }^{1}$ Laboratory of Cell Culture, Department of Morphology, Stomatology and Physiology, Ribeirão Preto Dental School, USP - University of São Paulo, Ribeirão Preto, SP, Brazil

${ }^{2}$ Laboratory of Molecular Biology, Department of Oral Maxillofacial Surgery and Periodontology,
\end{abstract} \\ Ribeirão Preto Dental School, USP - University of São Paulo, Ribeirão Preto, SP, Brazil
}

\begin{abstract}
The aim of this study was to evaluate the odontogenic potential of undifferentiated pulp cells (OD-21 cell line) through chemical stimuli in vitro. Cells were divided into uninduced cells (OD-21), induced cells (OD-21 cultured in supplemented medium/OD-21+OM) and odontoblast-like cells (MDPC-23 cell line). After 3, 7, 10 and 14 days of culture, it was evaluated: proliferation and cell viability, alkaline phosphatase activity, total protein content, mineralization, immunolocalization of dentin matrix acidic phosphoprotein 1 (DMP1), alkaline phosphatase (ALP) and osteopontin (OPN) and quantification of genes ALP, OSTERIX (Osx), DMP1 and runtrelated transcription factor 2 (RUNX2) through real-time polymerase chain reaction (PCR). Data were analyzed by Kruskal-Wallis and Mann-Whitney U tests $(\mathrm{p}<0.05)$. There was a decrease in cell proliferation in OD- $11+\mathrm{OM}$, whereas cell viability was similar in all groups, except at 7 days. The amount of total protein was higher in group OD-21 + OM in all periods; the same occurred with ALP activity after 10 days when compared with OD-21, with no significant differences from the MDPC-23 group. Mineralization was higher in OD-21+OM when compared with the negative control. Immunolocalization demonstrated that DMP1 and ALP were highly expressed in MDPC-23 cells and OD-21 + OM cells, whereas OPN was high in all groups. Real-time PCR revealed that DMP1 and ALP expression was higher in MDPC-23 cell cultures, whereas RUNX2 was lower for these cells and higher for OD-21 negative control. Osx expression was lower for OD-21 + OM. These results suggest that OD-21 undifferentiated pulp cells have odontogenic potential and could be used in dental tissue engineering.
\end{abstract}

Key Words: OD-21 undifferentiated pulp cells, odontoblast-like cells, odontogenic potential.

\section{INTRODUCTION}

The knowledge generated through basic science research in the fields of stem cell biology, biomaterials and odontogenesis, coupled with recent advances in clinical research in Endodontics, has come together at a time when tissue engineering-based therapies are being translated to clinical practice in Medicine (1). Dental implants are one method of oral rehabilitation fairly investigated and well accepted in dental practice, but factors such as location, blood supply, quality and quantity of bone tissue may interfere with osseointegration and lead to success or failure of this therapy (2). The advancement of stem cell research sparked great interest in cultivating them in the presence of signs of odontogenic induction, scheduling them in differentiation of dental cell lineages and, with the aid of a scaffold/extracellular matrix, form a new tooth (3). Dental stem cells display multifactorial potential such as high proliferation rate, multi-differentiation ability, easy accessibility, high viability and easiness to be induced to distinct cell lineages (4).

When odontoblasts are destroyed by caries or restorative procedures, the replacement of these cells can be performed by dental pulp stem cells, which might differentiate into odontoblasts and form reparative dentin

Correspondence: Profa. Dra. Karina Fittipaldi Bombonato Prado, Laboratório de Cultura de Células, Departmento de Morfologia, Estomatologia e Fisiologia, Faculdade de Odontologia de Ribeirão Preto, USP, Avenida do Café, S/N, 14040-904 Ribeirão Preto, SP, Brasil. Tel: +55-16-3602-4052. Fax: +55-16-3602-4794. e-mail: karina@forp.usp.br 
(5). Established cell lines derived from odontoblast-like cells are very useful for a variety of purposes such as to study the synthesis of specific molecules including proteins and mRNA, and the processes of dentinogenesis. This model system can also be employed to study the effects of a variety of molecules such as hormones, growth factors and cytokines on cellular function, in addition to tests with biomaterials or environmental situations with possible effects on odontogenesis (6). Two murine cell lines were developed by Hanks et al. (6), derived from undifferentiated pulp cells (OD-21) and odontoblasts (MDPC-23). Both were developed as spontaneously immortalized cell lines derived from dental papilla cells of the first molar of fetal mice. OD21 cells are characterized by expressing high baseline of Vascular endothelial growth factor (VEGF) (7), which is found in dentin matrix and its release during caries progression might contribute to the reparative response of pulp-dentinal complex (8). On the other hand, the absence of expression of some markers of odontoblastic activity, such as dentin phosphophoryn (DPP) and dentin sialoprotein (DSP) has been observed in OD-21 cell culture (6). In spite of that, under appropriate conditions, these cells can exhibit mineralization (9).

The purposes of this work were to evaluate the odontogenic potential of OD-21 undifferentiated pulp cells through chemical stimuli in vitro, and to compare the results with those of MDPC-23 cell line, using the following parameters: cell proliferation, cell viability, activity of alkaline phosphatase (ALP), total protein content, detection and quantification of mineralized matrix, immunolocalization of non-collagen proteins (DMP1, ALP and OPN) and real-time polymerase chain reaction (PCR) of genes ALP, DMP1, OSTERIX and RUNX2.

\section{MATERIAL AND METHODS}

\section{Cell Culture}

Two mouse cell lines were used: odontoblast-like cells (MDPC-23) and undifferentiated dental pulp cells (OD-21) (7). The cells were cultured in Dulbecco's Modified Eagle's medium (DMEM, Gibco BRL, Grand Island, NY, USA), supplemented with 10\% fetal bovine serum (Gibco, Grand Island, NY, USA), $200 \mathrm{mM}$ L-glutamine (Gibco), 50-units/mL penicillin (Gibco), and $50 \mu \mu \mathrm{g} / \mathrm{mL}$ streptomycin (Gibco) in a humidified $5 \% \mathrm{CO}_{2}$ incubator at $37^{\circ} \mathrm{C}$.
Differentiation of OD-21 cells was induced through the addition of $50 \mu \mathrm{g}$ of ascorbic acid to promote collagen and extracellular matrix formation and $2 \mathrm{mM}$ beta-glycerophosphate to formation and mineralization of nodules in multilayers. MDPC-23 cells received the same supplemented medium. Uninduced OD-21 cells were also cultured and remained as negative control. Subconfluent cells were harvested after treatment with $1 \mathrm{mM}$ EDTA (Gibco) and $0.25 \%$ trypsin (Gibco) and subcultured in 24-well polystyrene plates (Falcon; Franklin Lakes,NJ, USA) at a density of 104 cells/well $(n=5)$.

\section{Total Cell Number and Viability}

Cells grown for periods of 3, 7 and 10 days were enzymatically detached using $1.3 \mathrm{mg} / \mathrm{mL}$ collagenase and $0.25 \%$ trypsin solution (Gibco). Total number of cells/ well was determined after Trypan blue (Sigma-Aldrich, St. Louis, MO, USA) staining using a hemacytometer (Hausser Scientific, Horsham, PA, USA).

\section{Total Protein Content and Alkaline Phosphatase Activity}

Total protein content was determined at days 3 , 7 and 10 . Briefly, proteins were extracted from each well with $0.1 \%$ sodium lauryl sulfate (Sigma-Aldrich) for 30 min and mixed 1:1 with Lowry solution (SigmaAldrich) for $20 \mathrm{~min}$ at RT. The extract was diluted in Folin and Ciocalteau's phenol reagent (Sigma-Aldrich) for $30 \mathrm{~min}$ at RT. Absorbance was measured at $680 \mathrm{~nm}$ using a spectrophotometer (Cecil CE3021, Cambridge, UK). The total protein content was calculated from a standard curve and expressed as $\mu \mathrm{g} / \mathrm{mL}$, which was then normalized by the number of cells.

Alkaline phosphatase (ALP) activity was assayed in the same lysates used for determining total protein content as the release of thymolphthalein from thymolphthalein monophosphate by using a commercial kit (Labtest Diagnóstica, Lagoa Santa, MG, Brazil). Briefly, $50 \mu$ L of thymolphthalein monophosphate were mixed with $0.5 \mathrm{~mL}$ of $0.3 \mathrm{M}$ diethanolamine buffer, $\mathrm{pH}$ 10.1 , and left for $2 \mathrm{~min}$ at $37^{\circ} \mathrm{C}$. The solution was then added to $50 \mu \mathrm{L}$ of the lysates obtained from each well for $10 \mathrm{~min}$ at $37^{\circ} \mathrm{C}$. For color development, $2 \mathrm{~mL}$ of 0.09 $\mathrm{M} \mathrm{Na}_{2} \mathrm{CO}_{3}$ and $0.25 \mathrm{M} \mathrm{NaOH}$ were added. After $30 \mathrm{~min}$, absorbance was measured using a spectrophotometer (CE3021) at $590 \mathrm{~nm}$ and ALP activity was calculated 
from a standard curve using thymolphthalein to give a range from 0.012 to $0.4 \mu \mathrm{mol}$ thymolphthalein $/ \mathrm{h} / \mathrm{mL}$. Data were expressed as ALP activity normalized by the number of cells.

\section{Mineralized Matrix Formation}

Mineralized matrix formation was detected at day 14 by Alizarin Red S (Sigma-Aldrich) that stains areas rich in calcium. Attached cells were fixed in 10\% formalin for $2 \mathrm{~h}$ at room temperature. After fixation, the specimens were dehydrated through a graded series of alcohol and stained with 2\% Alizarin Red S, pH 4.2, for $10 \mathrm{~min}$. The calcium content was evaluated using a colorimetric method. Briefly, $280 \mu \mathrm{L}$ of $10 \%$ acetic acid was added to each well stained with Alizarin Red S, and the plate was incubated at RT for 30 min under shaking. This solution was transferred to a microcentrifugue tube and after vortexing for $1 \mathrm{~min}$, the slurry was overlaid with $100 \mu \mathrm{L}$ of mineral oil (Sigma-Aldrich), heated to exactly $85^{\circ} \mathrm{C}$ for $10 \mathrm{~min}$, and transferred to ice for 5 $\mathrm{min}$. The slurry was then centrifuged at 20,000 $\mathrm{g}$ for 15 min and $100 \mu \mathrm{L}$ of supernatant was transferred to a new microcentrifugue tube. Then, $40 \mu \mathrm{L}$ of $10 \%$ ammonium hydroxide was added to neutralize the acid and this solution containing $140 \mu \mathrm{L}$ was read at $405 \mathrm{~nm}$ in 96well format using opaque-walled transparent-bottomed plates (Fisher Scientific, Pittsburgh, PA, USA) on the plate reader $\mu$ Quant (Biotek, Winooski, VT, USA). Data were expressed as absorbance values.

\section{Immunolabeling}

Cells were cultured on Thermanox ${ }^{\circledR}$ Plastic coverslips (Nunc, Roskilde, Danmark) and after 3 days they were fixed at room temperature with $4 \%$ paraformaldehyde (Acros Organics, New Jersey, NJ, USA) in $0.1 \mathrm{M}$ phosphate buffer (PB) (Acros Organics), $\mathrm{pH} 7.2$ for $10 \mathrm{~min}$. After washing in $\mathrm{PB}$, cells were routinely processed for immunofluorescence labeling for detection of alkaline phosphatase (ALP), osteopontin $(\mathrm{OPN})$ and dentin matrix acidic phosphoprotein 1 (DMP1). Cells fixed with paraformaldehyde were permeabilized with $0.5 \%$ Triton X-100 (Acros Organics) in PB for $10 \mathrm{~min}$. Then, the samples were blocked with $5 \%$ skimmed milk in PB for 30 min. Primary antibodies to ALP (monoclonal B4-78, 1:100; Developmental Studies Hybridoma Bank, Iowa City, IA, USA), OPN (monoclonal MPIIIB10, 1:800, Developmental Studies
Hybridoma Bank, Iowa City, IA) and DMP1 (polyclonal LF-148, 1:1000, Dr Larry W. Fisher, National Institutes of Health, Bethesda, MD, USA) were used, followed by goat anti-mouse (ALP and OPN) and goat anti-rabbit (DMP1) secondary antibody (1:200; Molecular Probes, Eugene, OR, USA), conjugated with Alexa Fluor 594 (red fluorescence) and Alexa Fluor 488-conjugated phalloidin (1:200; Molecular Probes) for actin staining. All antibody incubations were performed in a humidified environment for $60 \mathrm{~min}$ at room temperature. Between each incubation step, the samples were washed 3 times (5 min each) in PB. Before mounting for microscope observation, cell nuclei were stained with $300 \mathrm{nM}$ 4',6-diamidino2-phenylindole, dihydrochloride (DAPI; Molecular Probes) for $5 \mathrm{~min}$ and samples were briefly washed with $\mathrm{dH} 2 \mathrm{O}$. The Thermanox coverslips were placed on microscope slides (Knittel, Braunschweig, Germany) and Fisherbrand $12 \mathrm{~mm}$-round glass coverslips (Fisher Scientific) were mounted with an antifade kit (Prolong; Molecular Probes) on the surface containing cells. The samples were examined under epifluorescence using a Leica DMLB light microscope, with N Plan (310/0.25, 320/0.40) and HCX PL Fluotar (340/0.75) objectives, outfitted with a Leica DC 300F digital camera (Leica; Bensheim, Germany). The acquired digital images were processed with Adobe Photoshop software (Adobe Systems Inc., San Jose, CA, USA).

RNA Extraction and Quantitative Real-Time Reverse Transcriptase-Polymerase Chain Reaction (RT-PCR)

Gene expression of ALP, DMP1, OSTERIX and RUNX2 were evaluated by means of RT-PCR after 7 days. TaqMan ${ }^{\circledR}$ Gene Expression Assays (Applied Biosystems, Warrington, UK, USA) were acquired for each gene (RUNX2 Mm 01208365_m1; OSTERIX Mm 00504574_m1; DMP1 Mm 03003491_m1and ALPMm 01187117). The total RNA from cells was extracted using the Promega RNA extraction kit (Promega, Madison, WI, USA), according to the manufacturer's instructions. The concentration of RNA was determined by optical density at a wavelength of $260 \mathrm{~nm}$, using the Biomate 3 spectrophotometer (Thermospectronic, Rochester, NY, USA). Complementary DNA (cDNA) was synthesized using $2 \mu \mathrm{g}$ of RNA through a reverse transcription reaction (M-MLV reverse transcriptase, Promega). RT-PCR was performed in a CFX96 ${ }^{\mathrm{TM}}$ Real-Time PCR Detection System (Bio-Rad Laboratories, Inc., Hercules, CA, USA) using TaqMan ${ }^{\circledR}$ Gene Expression Assays. 
Each reaction was performed using $5 \mu \mathrm{L}$ de Taqman ${ }^{\circledR}$ Universal PCR Master Mix UNG (2X)2, 0,5 $\mu \mathrm{L}$ de (20X) Taqman ${ }^{\circledR}$ Gene Expression Assay Mix and 4,5 $\mu \mathrm{L}$ de cDNA $(11,25 \mathrm{ng})$, with a final volume of $10 \mu \mathrm{L} /$ reaction. The standard PCR conditions were $50^{\circ} \mathrm{C}(2 \mathrm{~min}), 95^{\circ} \mathrm{C}$ (10 min) and 40 cycles of $95^{\circ} \mathrm{C}(15 \mathrm{~s}), 60^{\circ} \mathrm{C}(1 \mathrm{~min})$. To mRNA analysis, the relative level of gene expression was calculated in reference to GAPDH expression and normalized by the gene expression of control culture (calibrator) using the cycle threshold $(\mathrm{Ct})$ method.

\section{Statistical Analysis}

Data were analyzed by SPSS statistical software, version 17.0 (SPSS, Chicago, IL, USA), using the Kruskal-Wallis test followed by Mann-Whitney U test. Three independent experiments for each assay described above were performed to demonstrate reproducibility of the data. Each individual experiment was performed in quintuplicate $(\mathrm{n}=5)$ to allow for determination of averages and standard deviation. The significance level of the data was determined at $\mathrm{p} \leq 0.05$.

\section{RESULTS}

\section{Total Cell Number and Viability}

The total cell number showed no significant difference among the experimental groups after three days. On the other hand, after 7 and 10 days, the total cell

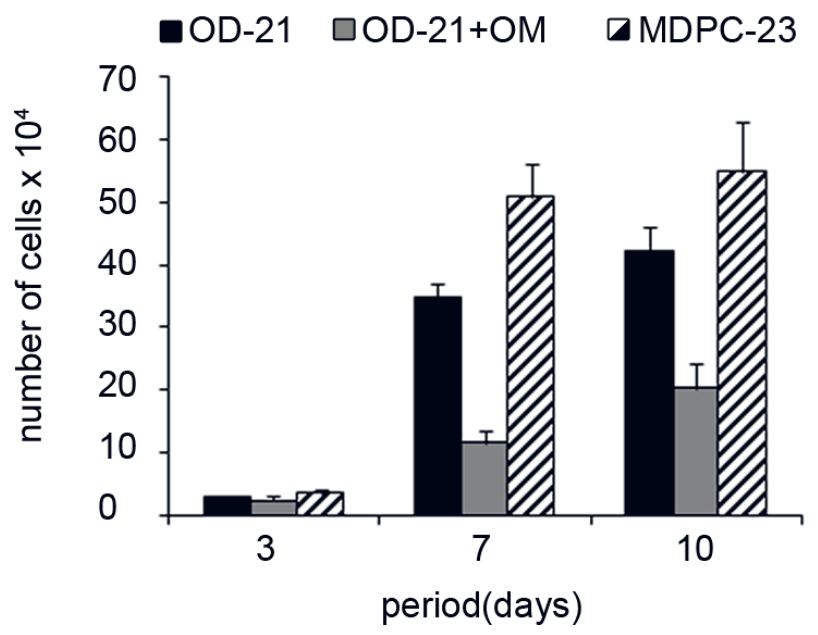

Figure 1. Cell proliferation expressed as number of cells $\times 10^{4} /$ well after 3, 7 and 10 days of culture. Data are reported as mean $\pm \mathrm{SD}(n=5)$. number was significantly smaller for cultures exposed to OM $(p<0.05)$, whereas MDPC-23 cells showed higher proliferation $(\mathrm{p}<0.05)$ when compared with the other two groups (Fig. 1). Additionally, cell viability was similar to all groups after 3 and 10 days; after 7 days, the viability of cells exposed to $\mathrm{OM}$ was significantly smaller ( $<<0.05$ ) (Fig. 2).

\section{Total Protein Content (TPC)}

There was a decrease in TPC until ten days regarding all the studied groups. Observing each group individually, there was no statistically significant difference in TPC among the groups after three days. On the other hand, after 7 and 10 days, the TPC was significantly higher for cultures grown in the presence of OM, when compared with the other groups $(\mathrm{p}<0.01)$ (Fig. 3).

\section{ALP Activity}

All the groups presented an increase in the level of ALP activity until 10 days. After 3 days, OD-21+OM group had higher ALP activity when compared with MDPC-23 cells group $(p<0.01)$. On the other hand, after 7 days, odontoblast-like cells showed the higher level of ALP when compared with the other two groups ( $p<0.01)$. The cells exposed to OM after 10 days showed similar levels of ALP activity when compared with MDPC-23 cells, and both were significantly higher when compared

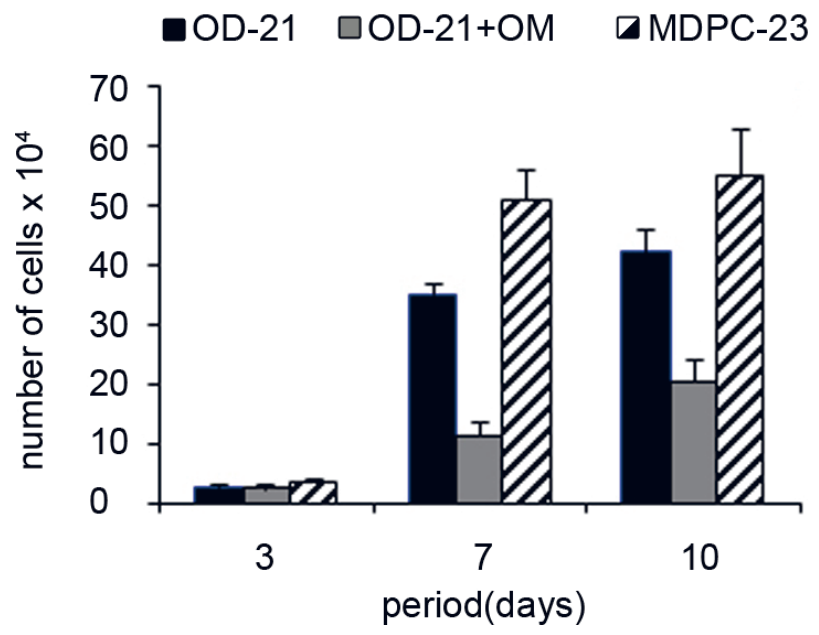

Figure 2. Cell viability expressed as percentage of viable cells after 3, 7 and 10 days of culture. Data are reported as mean \pm $\mathrm{SD}(n=5)$. 
with negative control ( $\mathrm{p}<0.01)$ (Fig. 4).

\section{Mineralized Matrix Formation}

Mineralized nodules were detected in MDPC-23 culture plate, but not at OD-21 group. OD-21 group exposed to OM showed a great amount of nodules, despite being smaller than odontoblast-like cells group. In the same way, calcium content measured by the extraction of Alizarin Red S from mineralized matrix after 14 days demonstrated that OD-21 cell culture

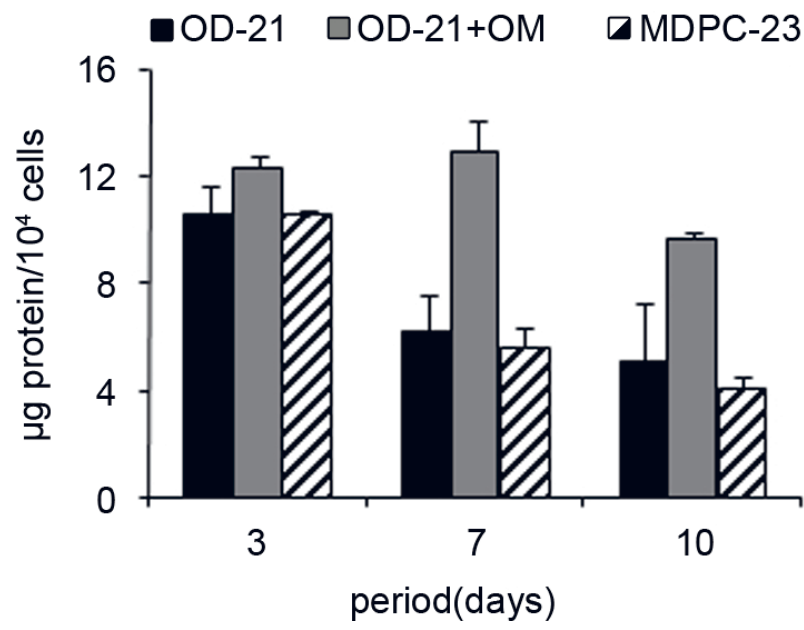

Figure 3. Total protein content expressed as $\mu \mathrm{g}$ of protein per number of cells at 3, 7 and 10 days of culture. Data are reported as mean $\pm \mathrm{SD}(n=5)$.
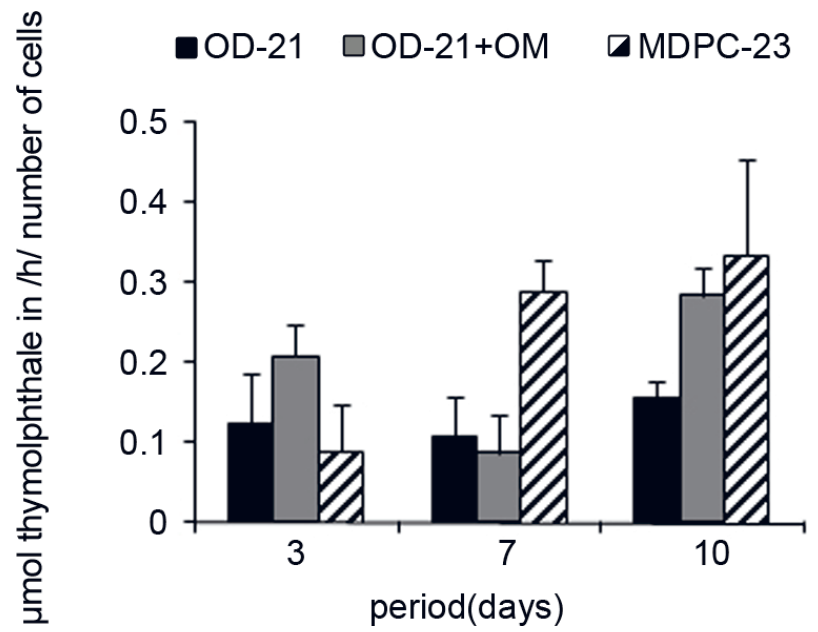

Figure 4. Alkaline phosphatase (ALP) activity expressed as $\mu \mathrm{mol}$ thymolphthalein/h per number of cells after 3, 7 and 10 days of culture. Data are reported as mean $\pm \mathrm{SD}(n=5)$. exposed to OM contained significantly more calcium than the negative control (OD-21) $(\mathrm{p}<0.01)$, despite MDPC-23 showing more calcium compared with the other two groups $(\mathrm{p}<0.01)$ (Fig. 5).

\section{Immunolabeling}

Cell morphology can be seen in Figure 6, demonstrating that MDPC-23 cells are epithelioid and round in shape with multiple cell membrane processes and organized in groups. On the other hand, OD-21 cells are elongated, as well as distributed throughout the field. OD-21 cells exposed to OM had their morphology and distribution slightly modified, with some cells acquiring a polygonal shape. Immunolocalization after 3 days showed that DMP1 protein was highly expressed in MDPC-23 cells and OD-21 + OM cells, when compared with negative control. ALP expression was higher in MDPC-23, followed by OD-21 + OM group and OD-21 group. OPN expression was high in all groups, especially in MDPC-23 and OD-21 groups.

\section{Real-Time PCR}

After 7 days, gene expression of ALP was lower in OD-21 +OM group (Fig. 7A) when compared with the other two $(p<0.05)$, whereas DMP1 expression was significantly higher $(\mathrm{p}<0.05)$ in MDPC-23 cell cultures (Fig. 7B). The expression of OSTERIX gene was lower for OD-21 $+\mathrm{OM}(\mathrm{p}<0.05)$ when compared with the other

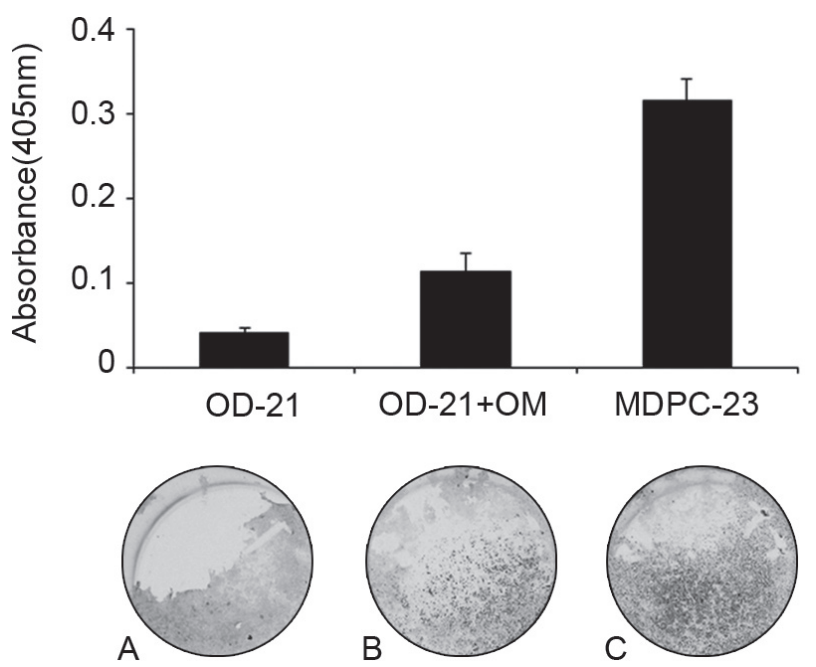

Figure 5. Mineralized nodules in OD-21 (A), OD-21 + OM (B) and MDPC-23 (C) culture plates and calcium detection after 14 days of culture. Data are reported as mean $\pm \mathrm{SD}(n=5)$. 
groups (Fig. 7C). In the case of RUNX2, its expression was higher for OD-21 group when compared with the other groups, which had no statistical difference between them $(\mathrm{p}<0.05)($ Fig. 7D).

\section{DISCUSSION}

In response to mild environmental stimuli (attrition or early caries), pre-existing live odontoblasts
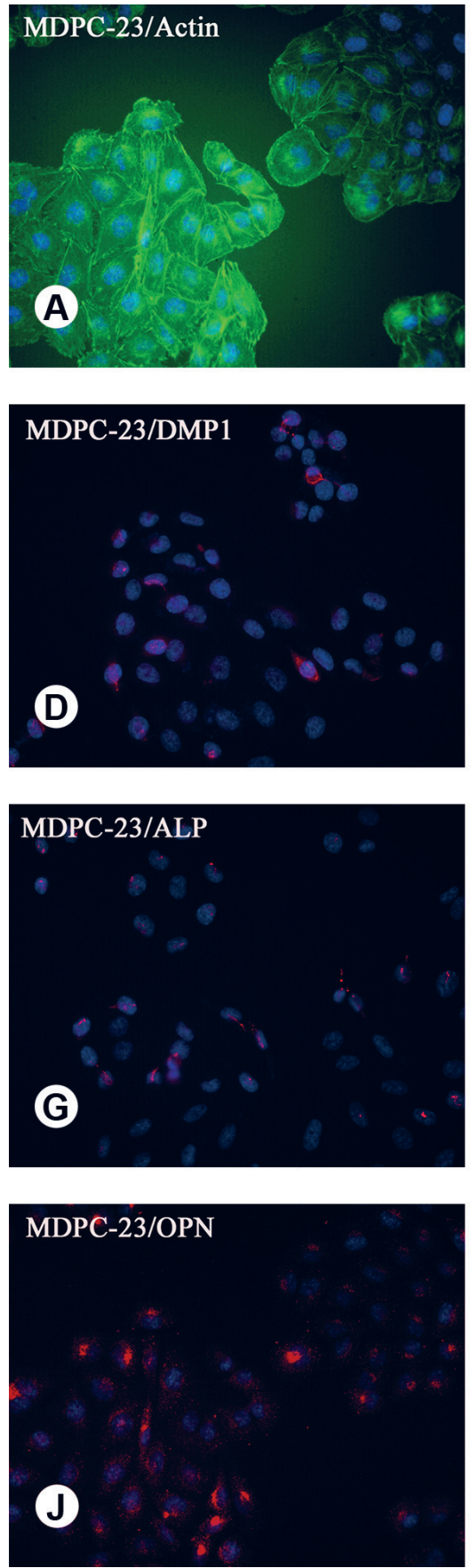
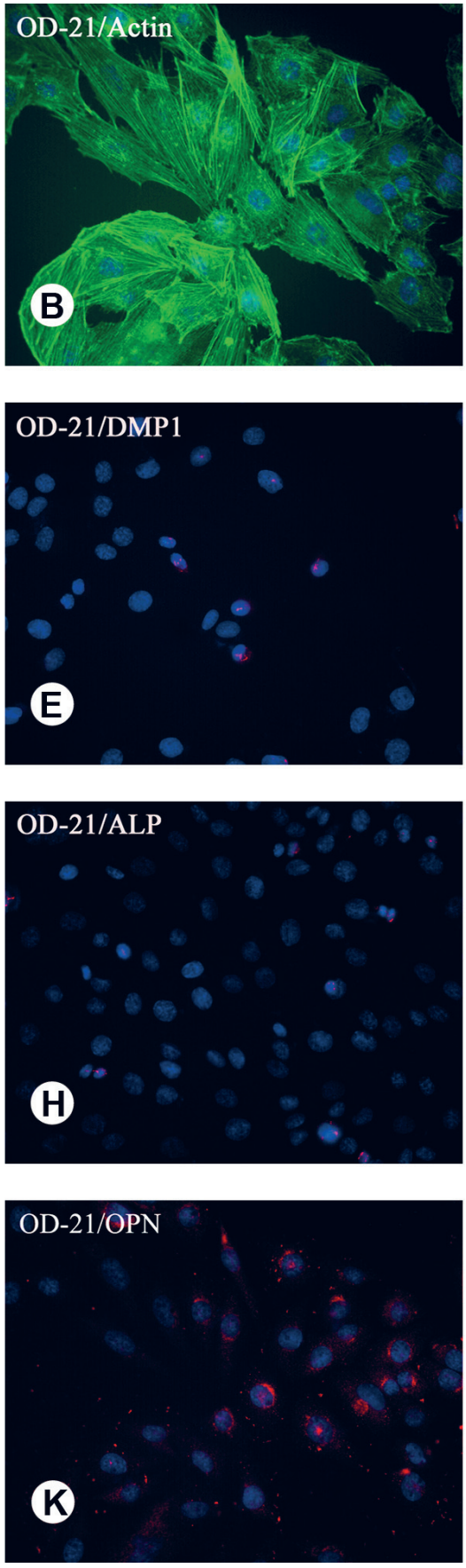
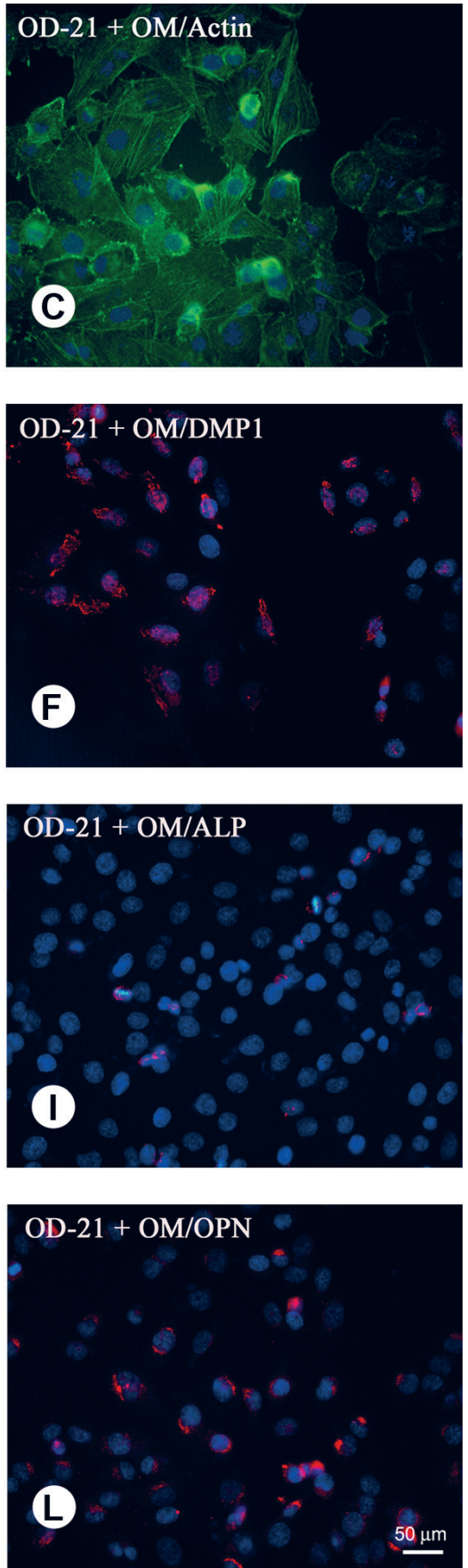

Figure 6. Fluorescence labeling preparations of protein expression in mouse odontoblastic cell cultures grown on Thermanox ${ }^{\circledR}$ coverslips divided into groups: MDPC-23, OD-21 and OD-21 + OM (after 3 days of culture). Green fluorescence (Alexa Fluor 488-conjugated phalloidin) reveals actin cytoskeleton while blue fluorescence (DAPI DNA stain) highlights cell nuclei (A, B, C). DMP1 (D, E, F), $\operatorname{ALP}(\mathrm{G}, \mathrm{H}, \mathrm{I})$ and $\mathrm{OPN}(\mathrm{J}, \mathrm{K}, \mathrm{L})$ immunolabelling are expressed in red fluorescence . Scale bar $=50 \mu \mathrm{m}$. 
upregulate their secretory activity and secrete a tubular reactionary dentin matrix (10). On the other hand, strong noxious stimuli (deep caries or pulp exposure) that lead to destruction of existing odontoblasts is followed by formation of reparative dentin secreted by a new generation of odontoblast-like cells derived from dental pulp (11). Reparative dentinogenesis is thought to be dependent on multiple signaling molecules sequestrated in the dentin matrix $(12,13)$. Thus, potential populations of cells within dental pulp capable of giving rise to the new generation of odontoblast-like cells during reparative dentinogenesis are numerous and include the cell-rich layer of Höhl adjacent to the odontoblasts, undifferentiated mesenchymal cells and fibroblasts (10).

Reports related that dental pulp stem cells (DPSCs) isolated from human teeth have the potential of differentiation into odontoblasts (14), showing the capability of these cells to produce mineralized nodules after odonto/osteogenic induction, as well as positivity for markers of both osteogenic and odontogenic differentiation, including ALP, bone sialoprotein (BSP), and dentin sialoprotein (DSP) (15). The same way, PCR data presented in the literature demonstrate that the $\mathrm{Ca}(\mathrm{OH})_{2}$ solubilized dentin matrix can induce changes in gene expression pattern in several cell types commonly encountered in pulp, including fibroblasts as well in OD-21 and MDPC-23 cell lines, representative of undifferentiated pulp mesenchymal cells and odontoblast-like cells respectively (12), also used in the present investigation. The present study confirmed the in vitro odontogenic potential of OD-21 undifferentiated pulp cells murine cell line.

It was also observed a decrease in the proliferation rate of OD-21 + OM group, especially after 7 and 10 days of culture. The low proliferation rate found in our study might be correlated to a beginning of cell differentiation, supported by investigations with odontoblastic cells (16), which reported that differentiation is preceded by the reduction of cell growth. Thus, a reciprocal relationship between a decrease in cell proliferation and subsequent induction of functional activity might have occurred. In the present investigation, this stimulation of cell function might be demonstrated by the increase in the total protein content in induced cells, in all periods.

Alkaline phosphatase, an early marker of odonto/ osteogenesis, showed a higher activity in induced OD21 cells after 10 days when compared with uninduced cells (negative control). Plus, there was no statistically
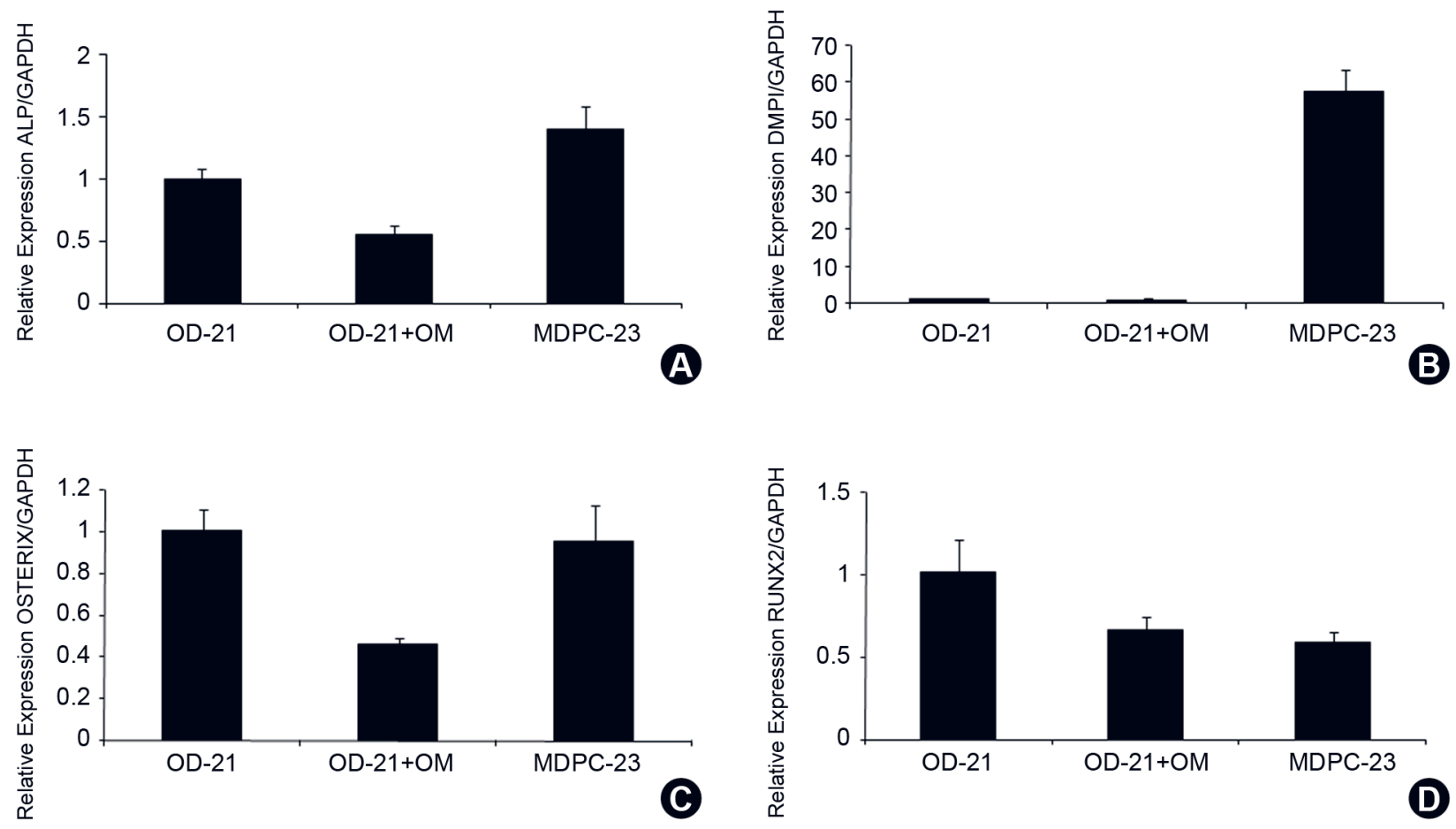

Figure 7. Real-time PCR gene expression of ALP (A), DMP1(B), OSTERIX (C) and RUNX2 (D) after 7 days of culture in OD-21, OD-21 + OM and MDPC-23 groups. Data are reported as mean $\pm \mathrm{SD}(n=5)$. 
significant difference between induced undifferentiated pulp cells and odontoblast-like cells (MDPC-23). ALP, which has been proposed to stimulate mineralization by supplying phosphate or by splitting away inorganic pyrophosphate, is regarded as an important tool for odontoblast differentiation and dentin biomineralization (17). It was also observed a correlation between the high levels of ALP and an increase in mineralized nodules in OD-21 + OM group, as seen through alizarin red staining and colorimetric detection.

The present immunolocalization study demonstrated that DMP1 was expressed in the initial period of culture in odontoblast-like cells more than in undifferentiated pulp cells. Nevertheless, these cells treated with odontogenic medium showed high DMP1 expression, suggesting that this protein plays a role regulating specific genes controlling odontoblast-like differentiation (18). Those authors additionally showed that DMP1 is expressed in the odontoblast-like cells aligned along the reparative dentin-pulp interface. ALP is a protein associated with osteogenic and odontogenic differentiation, and in the present study this protein can be seen expressed mainly in the odontoblast-like cells and induced groups as early as 3 days, suggesting its role in cell differentiation. Some proteins, even not representing specific markers of odontoblastic differentiation, might be normally expressed during reparative dentinogenesis by functional odontoblasts secreting dentin matrix (19). It is the case of osteopontin (OPN), whose expression at an early developmental stage is an indication of its importance as a component in the formation of mineralized tissues like bone and dentin (20). It was also demonstrated that OPN was highly and similar expressed in perinuclear and cytoplasmic regions of odontoblast-like cells as well as in induced and uninduced OD-21 cell groups.

Other important tool used in this investigation was the evaluation of changes in gene expression that may lead to variations in cell functional activity, which are likely to contribute to the regenerative processes observed during dentin formation (12). Analysis of the three groups showed that the patterns of expression of ALP, DMP1, OSTERIX and RUNX2 were distinct after 7 days of culture. ALP expression was lower in the induced undifferentiated pulp cells when compared with the uninduced group. This may suggest that immature cells may contain more odontoblast progenitors and have greater dentinogenic ability necessary for mineralized tissue maturation (21). In the present investigation,
DMP1 was expressed by odontoblast-like cells. The levels of DMP1 were significantly increased at day 7 in MDPC-23 cells when compared with induced and uninduced undifferentiated pulp cells. The low levels of DMP1 in the OD-21 cells at this period are corroborated by other investigations (10), demonstrating that DMP1 gene was not detected at day 7, appeared at day 14 and increased at day 21 . These data suggest that its expression occurs at later stages, playing a role in biomineralization, regulation of phosphate homeostasis and cell differentiation (22). OSTERIX had its expression higher in OD-21 and MDPC-23 cell groups when compared with OD-21 + OM, indicating that chemical stimuli used in our experiments did not favor the expression of this gene, which has been shown to be expressed in differentiated odontoblasts and to be associated with cell differentiation and tooth-related gene expression at the later stages of tooth development via a RUNX2-independent signaling pathway (23).

Regarding RUNX2 expression, there were higher levels in the negative control (OD-21) when compared with the other groups. This can be explained by the fact that RUNX2 is essential for tooth development up to the bell stage, being necessary for the formation of the enamel knot, which controls growth and folding of the enamel organ epithelium (24). Other authors corroborate our findings showing that RUNX2 (type II) is strongly expressed in dental papilla mesenchyme, with up-regulation in pre-odontoblasts and no expression in differentiated odontoblasts (25). The results obtained in this investigation suggest that OD-21 undifferentiated pulp cells have potentiality to differentiate into odontoblast-like cells via chemical stimuli, emphasizing the importance of these cells in the process of odontogenesis as well as tissue regeneration.

\section{RESUMO}

O objetivo foi avaliar o potencial odontogênico de células indiferenciadas da polpa (OD-21) por meio de indução química in vitro. As células foram divididas em grupos: controle (OD-21), induzido (OD-21 em meio suplementado/OD-21 + OM), e células odontoblastóides (MDPC-23). Após 3, 7, 10 e 14 dias, avaliouse proliferação e viabilidade celular, proteína total e fosfatase alcalina (ALP), mineralização, imunolocalização da proteína da matriz dentinária 1 (DMP1), ALP e osteopontina (OPN), assim como a expressão dos genes ALP, OSTERIX (Osx), DMP1 e fator de transcrição RUNX2 por PCR em tempo real. Os dados foram avaliados pelo teste de Kruskal-Wallis seguido pelo teste de Mann-Whitney $U(p \leq 0.05)$. Houve diminuição na proliferação celular em OD-21 + OM, com viabilidade celular similar em todos os grupos, exceto aos sete dias. O conteúdo de proteína 
total foi maior no grupo OD-21 + OM em todos os períodos; o mesmo ocorreu com a atividade de ALP quando comparada com o grupo OD-21, além de apresentar resultados similares ao grupo MDPC-23. A mineralização foi maior em OD-21 + OM quando comparada com o controle negativo. A imunolocalização demonstrou expressão de DMP1 e ALP em MDPC-23 e OD-21 $+\mathrm{OM}$, enquanto que todos os grupos foram positivos para OPN. A expressão gênica de DMP1 e ALP foi maior nas culturas de MDPC-23, enquanto que a de RUNX2 foi menor para estas células e maior no controle negativo. A expressão de OSTERIX foi menor em OD-21 + OM quando comparada aos outros grupos. Sugere-se que as células indiferenciadas da polpa da linhagem OD-21 apresentam potencial odontogênico e poderiam ser usadas para a engenharia tecidual.

\section{ACKNOWLEDGEMENTS}

The authors would like to thank the National Council of Scientific and Technological Development (CNPq, Brazil) and The São Paulo Research Foundation (FAPESP, Brazil) for funding. The authors also wish to express their gratitude to Dr. Jacques Eduardo Nör (University of Michigan, Ann Arbor, USA) for providing the cell lines to perform the experiments.

\section{REFERENCES}

1. Demarco FF, Conde MC, Cavalcanti BN, Casagrande L, Sakai VT, Nör JE. Dental pulp tissue engineering. Braz Dent J 2011;22:3-13.

2. Tolstunov L. Implant zones of the jaws: implant location and related success rate. J Oral Implantol 2007;33:211-220.

3. Yen AH, Sharpe PT. Stem cells and tooth tissue engineering. Cell Tissue Res 2008;331:359-372.

4. Estrela C, Alencar AH, Kitten GT, Vencio EF, Gava E. Mesenchymal stem cells in the dental tissues: perspectives for tissue regeneration. Braz Dent J 2011;22:91-98.

5. Ballini A, De Frenza G, Cantore S, Papa F, Grano M, Mastrangelo $\mathrm{F}$, et al.. In vitro stem cell cultures from human dental pulp and periodontal ligament: new prospects in dentistry. Int $\mathrm{J}$ Immunopathol Pharmacol 2007;20:9-16.

6. Hanks CT, Sun ZL, Fang DN. Cloned $3 \mathrm{~T} 6$ cell line from CD-1 mouse fetal molar dental papillae. Connect Tissue Res 1998;37:233-249.

7. Botero TM, Mantellini MG, Song W, Hanks CT, Nör JE. Effect of lipopolysaccharides on vascular endothelial growth factor expression in mouse pulp cells and macrophages. Eur J Oral Sci 2003;111:228-34.

8. Roberts-Clark DJ, Smith AJ. Angiogenic growth factors in human dentine matrix. Arch Oral Biol 2000;45;1013-1016.

9. Musson DS, McLachlan JL, Sloan AJ, Smith AJ, Cooper PR. Adrenomedullin is expressed during rodent dental tissue development and promotes cell growth and mineralization. Biol Cell 2010;102:145-57.

10. Balic A, Aguila HL, Caimano MJ, Francone VP, Mina M.
Characterization of stem and progenitor cells in the dental pulp of erupted and unerupted murine molars. Bone 2010;46:1639-1651.

11. Sloan AJ, Waddington RJ. Dental pulp stem cells: what, where, how? Int J Paediatr Dent 2009;19:61-70.

12. Graham L, Cooper PR, Cassidy N, Nor JE, Sloan AJ, Smith AJ The effect of calcium hydroxide on solubilisation of bio-active dentine matrix components. Biomaterials 2006;27:2865-2873.

13. Tomson PL, Grover LM, Lumley PJ, Sloan AJ, Smith AJ, Cooper PR. Dissolution of bio-active dentine matrix components by mineral trioxide aggregate. J Dent 2007;35:636-642.

14. Gronthos S, Mankani M, Brahim J, Robey PG, Shi S. Postnatal human dental pulp stem cells (DPSCs) in vitro and in vivo. Proc Natl Acad Sci U S A 2000;97:13625-13630.

15. Dissanayaka WL, Zhu X, Zhang C. Characterization of Dental Pulp Stem Cells Isolated from Canine Premolars. J Endod 2011;37:1074-1080

16. Nakasone N, Yoshie H, Ohshima H. An immunohistochemical study of the expression of heat-shock protein-25 and cell proliferation in the dental pulp and enamel organ during odontogenesis in rat molars. Arch Oral Biol 2006;51:378-386.

17. Pang JL, Wu BL, He WX, Zhang YQ, Zhao HP, Xie ZH. Effect of antisense oligonucleotide against mouse dentine matrix protein 1 on mineralization ability and calcium ions metabolism in odontoblast-like cell line MDPC-23. Int Endod J 2006;39:527537.

18. Aguiar MC, Arana-Chavez VE. Immunocytochemical detection of dentine matrix protein 1 in experimentally induced reactionary and reparative dentine in rat incisors. Arch Oral Biol 2010;55:210-214.

19. Bakopoulou A, Leyhausen G, Volk J, Tsiftsoglou A, Garefis P, Koidis P, et al.. Comparative analysis of in vitro osteo/odontogenic differentiation potential of human dental pulp stem cells (DPSCs) and stem cells from the apical papilla (SCAP). Arch Oral Biol 2011;56:709-721.

20. Butler WT. The nature and significance of osteopontin. Connec Tissue Res 1989;23:123-136.

21. Lei G, Yan M, Wang Z, Yu Y, Tang C, Wang Z, et al.. Dentinogenic capacity: immature root papilla stem cells versus mature root pulp stem cells. Biol Cell 2011;103:185-196.

22. Deshpande AS, Fang PA, Zhang X, Jayaraman T, Sfeir C, Beniash E. Primary structure and phosphorylation of dentin matrix protein 1 (dmp1) and dentin phosphophoryn (dpp) uniquely determine their role in biomineralization. Biomacromolecules 2011;12:29332945.

23. Ulsamer A, Ortuño MJ, Ruiz S, Susperregui AR, Osses N, Rosa JL, et al.. BMP-2 induces Osterix expression through up-regulation of Dlx 5 and its phosphorylation by p38. J Biol Chem 2008;283:38163826.

24. D'Souza RN, Aberg T, Gaikwad J, Cavender A, Owen M, Karsenty G, et al.. Cbfa1 is required for epithelial-mesenchymal interactions regulating tooth development in mice. Development 1999;126:2911-2920.

25. Camilleri S, McDonald F. Runx2 and dental development. Eur J Oral Sci 2006;114:361-373.

Received November 3, 2011 Accepted April 13, 2012 